\title{
Analisis Model Tripel Helix Dalam Pengembangan Ekonomi (Studi Pada IKM Kerajinan Perak Mojokerto)
}

\begin{tabular}{l} 
Dosen Man \\
\hline Article Info \\
\hline Article history: \\
Received Desember 2021 \\
Publish 04 Januari 2022 \\
\\
\\
\hline Keywords: \\
Creative Economy \\
Tiple Helix \\
Small and Medium Silver \\
Industry \\
Mojokerto
\end{tabular}

\begin{tabular}{l}
\hline Info Artikel \\
\hline Article history: \\
Diterima 25 Desember 2021 \\
Publis 04 Januari 2022
\end{tabular}
\begin{abstract}
Creative economy development aims to develop human resources so that they can compete with reliable quality. Rural areas, especially the Batankrajan Village area, are one of the areas in Mojokerto Regency that have the potential of creative human resources to improve the welfare of the local community. Batankrajan village and is the center of the silver industry which is quite potential as a competitive product and Mojokerto's leading commodity. The aims of this study were (1) to identify the conditions and needs for product development and market development of the craftsmen/performers of the silver craft business in Senta Batankrajan, Mojokerto, East Java, (2) to identify the problems faced by the craftsmen of silver crafts IKM in Mojokerto, East Java, especially in increasing competitiveness, (3) Analyzing the triple helix model in the development of the creative economy as a driving force for Mojokerto silver handicraft products to increase local innovative and creative products that are unique to the region and have high added value and are able to become regional icons. This research also identifies strengths, weaknesses, opportunities and threats that can be used as information to map the strengths and weaknesses of creative industry players so that strategies for developing the right Triple helix model can be formulated for business actors. This research produces an economic/creative industry model with a Triple helix approach that provides a role for stakeholders (government, universities and business actors) in advancing the creative industry in rural areas, especially the silver industry in the center of Batankrajan, Mojokerto. Several recommendations and the framework for developing the Triple Helix model in the development of the creative economy include: Institutional strengthening, through Joint Business Groups, in order to invest in product development and market penetration as well as facilitate the establishment of access to financial sources and market access, the creation and establishment of intensive communication between government, universities and creative industry players, as well as the establishment of community forums that involve the government, universities in the Mojokerto area and do not rule out universities outside Mojokerto as well as industry players that function as communication forums and as a means of coaching and training.

\begin{tabular}{l}
\hline ABSTRAK \\
\hline Pengembangan ekonomi kreatif bertujuan untuk mengembangkan sumber daya \\
manusia agar dapat bersaing dengan kualitas yang dapat diandalkan. Daerah \\
pedesaan, khususnya daerah Desa Batankrajan merupakan salahsatu wilayah di \\
Kabupaten Mojokerto yang memiliki pottensi sumber daya manusia yang kreatif \\
untuk meningkatkan kesejahteraan masyarakat setempat. Desa Batankrajan dan \\
merupakan sentra industri perak yang cukup potnesial sebagai produk yang bisa \\
berdaya saing dan komoditi unggulan Mojokerto. Tujuan penelitian ini adalah \\
(1)Mengidentifikasi kondisi dan kebutuhan pengembangan produk dan pasar para \\
pengrajin/Pelaku usaha kerajinan Perak di Senta Batankrajan, Mojokerto, Jawa \\
Timur, (2) Mengidentifikasi permasalahan para pengrajin IKM Kerajinan perak di \\
Mojokerto, Jawa Timur terutama dalam peningkatan daya saing, (3)Menganalisis \\
model triple helix dalam pengembangan ekonomi kreatif sebagai penggerak produk \\
kerajinan perak Mojokerto untuk meningkatkan produk inovatif dan kreatif lokal \\
yang bersifat unik khas daerah dan bernilai tambah tinggi dan mampu menjadi icon \\
daerah. Dalam penelitian ini jug dilakukan identifikasi kekuatan,kelemahan,peluang \\
dan ancaman yang dapat digunakan sebagai informasi untuk memetakan kekuatan \\
dan kelemahan pelaku industri kreatif sehingga dapat ditumuskan strategi
\end{tabular}
\end{abstract}


pengembangan model Triple helix yang tepat bagi pelaku usaha. Penelitian ini menghasilkan model ekonomi /industri kreatif dengan pendekatan Triple helix yang memberikan peranan bagi stakeholder (pemerintah,perguruan tinggi dan pelaku usaha) dalam memajukan inustri kreatif di pedesaan, khususnya industri perak di sentra Batankrajan,Mojokerto. Beberapa rekomendasi dam rangka pengembangan model Triple Helix dalam pengembangan ekonomi kreatif anta lain: Penguatan kelembagaan, melalui Kelompok Usaha Bersama, dalam rangka melakukan investasi pengembangan produk dan penetrasi pasar sekaligus memudahkan terbinanya akses terhadap sumber keuangan dan akses pasar, terciptanya dan terjalinnya komunikasi yang intensif antara pemerintah,perguruan tinggi dan pelaku industri kreatif, serta pembentukan forum komuitas yang melibatkan pemerintah,perguruan tinggi yang ada di wilayah Mojokerto dan tidak menutup kemungkinan perguruan tinggi di luar Mojokerto serta pelaku industri yang berfungsi sebgai forum komunikasi dan sebagai sarana pembinaan dan pelatihan.

This is an open access article under the Lisensi Creative Commons AtribusiBerbagiSerupa 4.0 Internasional

Corresponding Author:

Danarti Hariani,

Universitas Mohammad Husni Thamrin

Email: danartihariani22@gmail.com

\section{PENDAhULUAN}

Ekonomi kreatif adalah suatu konsep di era ekonomi baru yang mengintensifkan informasi dan dengan mengandalkan ide pengetahuan dari sumber daya manusia sebaai faktor produksi utama (Hawskin,2008). Pengembangan ekonomi kreatif di Indonesia secara sistematis dimulai dengan Instruksi Presiden no 6 tahun 2009 tentang Pengembangan ekonomi kreatif yang berhasil merumuskan Rencana Induk Pengembangan Ekonomi Kreatif Indonesia Tahun 2009 - 2025 oleh Kemeterian Perdagangan Republik Indonesia.

Ekonomi kreatif dapat menciptakan nilai tambah dengan basis pengetahuan, termasuk warisan budaya, dan teknologi yang sudah ada dari ide kreatif dan inovasi sampai ide kreatif terwujud menjadi karya kreatif yang dapat digunakan dan ada pasarnya. Kreativitas merupakan modal utama dalm menghadapi tantangan global. Bentuk-bentuk ekonomi kreatif selalu tampil dengan nilai tambah yang khas, menciptakan pasarnya sendiri sekaligus menyerap tenaga kerja serta pemasukan ekonomi.

Globalisasi dan perdagangan global merupakan sesuatu yang tidak terelakkan dari kemajuan teknologi, dimana sebagian besar wilayah dunia terhubung pada era ekonomi informasi ,tantangan globalisasi menjadi semakin nyata.. Dalam konteks bersaing, daya saing merupakan kunci utama untuk sukses bertahan.. Daya saing ini muncul tidak hanya dalam bentuk produk dalam jumlah banyak, namun juga berkualitas. Kualitas produk ini dapat diperoleh melalui pencitraan atau penciptaan produk-produk kreatif yang berbeda dengan wilayah lain. Diperlukan kreativitas yang tinggi dalam menciptakan produk-produk yang inovatif.. Hal ini berarti ekonomi kreatif menemukan eksistennya dan berkembang (Salman,2010)

Ekonomi kreatif telah dikembangkan di berbagai negara dan berdampak positif yang signifikan, antara lain: penyerapan tenaga kerja, penambahan pendapatan daerah hingga pencitraan wilayah. Pencitraan wilayah muncul ketika suatu wilayah terkenal karena produk kreatif yang dihasilkan. Dalam konteks yang lebih luas pencitraan wilayah engan ekonomi kreatif juga terkoneksi dengan berbagai sektor, diantaranya sektor wisata. Berbeda dengan industri manufaktur yang bertumpu pada kuantitas. Industri kreatif bertumpu pada kulitas sumber daya manusia,sehingga industri kreatif banyak muncul dari kelompok industri kecil dan menengah. Sebagai contoh industri 
kreatif distro memproduksi desain produksi dengan jumlah yang kecil, sehingga justu bisa memunculkan eksklusifitas bagi konsumen dan digemari konsumen.

Dalam konteks pengembangan ekonomi kreatif pada kota-kota di Indonesia, industri kreatif berpotensi berkembang di kota-kota besar atau kota-kota yang sudah dikenal. Hal ini terkait dengan ketersediaan SDM yang handal dan tersedianya jaringan pemasaran yang lebih baik dibandingkan kota-kota kecil, tapi tidak menutup kemungkinan kota-kota kecil di Indonesia untuk mengembangkan ekonomi kreatif. Jadi sejatinya sejumlah kota-kota di Indonesia berpotensi untuk mengembangkan ekonomi kreatif. Indonesia dikenal sebagai negara yang kaya budaya yang dapat mereprentasikan budayanya melalui cara-cara yang unik, inovatif dan kreatif.

Potensi industri kerajinan sebagai industri kreatif sat in sangat tinggi.Industri kerajinan dalam negeri lebih dar 696 unit dengan penyerapan tenaga kerja sebanyak 1,32 juta orang dengan nilai ekspor pada tahun 2017 sebanyak USD 776 juta, naik 3,8\% dibandingkan tahun 2016 sekitar USD 747 juta (Kementrian Perindustrian,2018). Industri kerajinan perak merupakan salah satu jenis industri di Indonesia Indonesia mampu bersaing di pasar internasional karena Indonesia memiliki keunggulan desain dan kulitas produk. Seiring dengan perkembangan teknologi,industri ini masih mengandalkan buatan tangan dari pengrajinannya dalam proses produksinya.

Mojokerto merupakan daerah sentra indstri kerajinan perak yang berkembang cukup pesat, tepatnya di Batan krajan kecamatan Gedeg, Mojokerto. Desa yang terletak di sebelah barat dan agak dalam dari Mojokerto ini teryata menyimpan potensi yang cukup besar sebagai sentra kerajinan perak. Produk-produk mereka terkenal hingga pasar Eropa yang dikelola oleh Usaha kecil Mengah (UKM) oleh para pengajin-pengrajin lokal yang berdomisili di Desa Batan krajan.Industri perak Batan krajan ini merupakan salah satu produk olahan industri kreatif di Indonesia yang merupakan produk pengembangan budaya warisan leluhur. Kerajinan perak Btan krajan Mojokerto ini yang merupakan unique product berbasis lokal dan mempunyai nilai tambah tinggi jika didukung oleh pengembanganteknologi,pengembaSDM,akses informasi, promosi dan bantuan permodalan. Selain itu produk ini didukung oleh Sentra Produksi Kerajinan,terutama di daerah Mojokerto,Jawa Timur,khususnya Desa Batankrajan,Kec.Gedeg yang merupakan sentra produksi kerajinan perak yang telah lama berkembang.

Permasalahan umum yang dihadapi di sentra produksi tersebut antara lain: desain masih monoton,kurang menarik dan terkesan kuno,belum menerapkan manajemen mutu, terbatasnya pendidikan dan informasi akan trend dan brpengaruh pada desain,sehingga menimbulkan perhiasan perak batankrajan tidak punya identitas dan eksklusifitas desain karena hanya menggantungkan desain dari pembeli-pembeli asing,majalah-majalah,televisi yang cenderung jarang menampilkan trend fashion yang sedang berkembang saat ini,Ktidakpercayaan pengusaha UKM untuk mengembangkan ide usahanya karena terbatasnya informasi dan kemampuan dalam menciptakan ide-ide yang inovatif da kreatif, kurangnya fasilitas perkenalan atau promosi perhiasan perak Batankrajan baik di dalam negaeri maupun luar negeri negeri, sehingga terkesan kurang dikenal pasar serta terbatasnya akses sumber pembiayaan. Untuk menciptakan produk kerajinan perak yang berorientasi global perlu peningkatan kompetensi SDM,Teknologi dan Pasarnya.

Berangkat dari permasalahan di atas, maka pengembangan ekonomi kreatif sebagai penggerak industri kerajinan perak Mojokerto perlu dilakukan untuk membeikan dampak positif yang akan berpengaruh terhadap kehidupan sosial, iklim bisnis, peningkatan ekonomi dan berdampak pada citra suatu kawasan tersebut, tak terkecuali Desa Batan krajan Mojokerto. Pada gilirannya nya pengembangan ekonomi kreatif akan berdampak pada perbaikan lingkungan kota,baik secara estetis maupun kualitas lingkungan.

Konsep daya saing suatu wilayah dapat diartikan sebagai kemampuan wilayah untuk berinovasi dalam menghadapi tantangan global. Wilayah Batankrajan sebagai wilayah unggulan industi perak Mojokerto harus mencari cara untuk mengatasi hambatan dan permasalahan yang dihadapi. Permasalahan di sentra preak Batan krajan,salahsatunya aadala belum adanya sinergi 
positif dan ptisipasi aktif secara optimal dalam mengembangkan industi perak Batankrajan Mojokerto.

Jejaring antar pihak-pihak ang terlibat dalam pengembangan masih lemah sehingga menyrbabkan kurangnya inovasi pada pengembangan wilayah industri peak Batankrajan. Daya saing industi perak Batankajan berdasarkan adanya jejaring lokal, seperti Pemerintah, Intelektual atau Universitas, dan Pelaku Usaha dalam mengembangkan inovasi di sebuah wilayah menjadi sangat penting,terutama yang berbasis industry perak. Model Triple Helix menyajikan transformasi atau perubahan peran dan interaksi antara akademisi, industri, dan pemerintah (Hamidah Nayati,2019). Oleh karena itu, penelitian ini bertujuan untuk mengetahui hubungan jejaring antar pihak-pihak yang telibat dalam pengembangan di sentra perak Batankrajan melalui pendekatan triple helix, mengingat jejaring sangat berperan dalam menghasilkan inovasi yang menjadi daya saing dari sebuah wilayah, dalam hal ini sentra industi perak Batankrajan. Dalam rangka menjawab tujuan tersebut, maka sasaan penelitian ini adalah dalam penelitian ini adalah: (1). Identifikasi peran pihak-pihak yang terlibat/jejaring dalam pengembangan sentra perak Batan Krajan; (2).Identifikasi hubungan jejaring antar pihak-pihak yang terlibat dalam pengembangan sentra industri perak Batan krajan, Mojokerto Jawa Timur.

\section{METODE PENELITIAN}

Peneltian ini dilakukan dengan pendekatan kualitatif dengan metode deskriptif .memberikan gambaran tentang kondisi faktual industri kecil menengah Perak Batankrajan, Mojokerto. Jawa Timur permasalahan-permasalahan yang dihadapi. Metode SWOT digunakan untuk merumuskan secara kualitatif dan holistik baik lingkungan internal maupun eksternal dari obyek yang diamati.Dalam linkup internal analisis akan menjelaskan secara rinci aspek-aspek yng akan menjadi kelemahan (weakness) dan kekuatan (strenght). Sementara dalam lingkup ekstrenal analisis ini akan menjelaskan secara rinci mengenai aspek peluang (opportunity) dan kendala (treats) usaha yang harus dihadapi.

Secara garis besar pengumpulan data dalam penelitian ini dilakukan melalui penggabungan berbagai teknik, yaitu wawancara mendalam, observasi ke lapangan, dan penelaahan dokumen yang relevan untuk mendapatkan data dari berbagai sumber. Dalam metode penelitian kualitatif informasi yang dikumpulkan dan diolah harus obyektif . Penelitian ini menfokuskan pada studi kasus yang merupakan penelitian rinci mengenai suatu obyek penelitian selama periode tertentu yang dilakukan. Selanjutnya berdasarkan hasil analisis SWOT dapat dilakukan analisis model tiple helix sesuai dengan teori yang dikemukakan oleh Etzkowitz (2008) menyatakan bahwa perkembangan inovasi di sebuah wilayah diciptakan dari adanya kolaborasi antara pemerintah, intelektual dan pelaku usaha yang memiliki hubungan yang erat dan saling menunjang dengan memanfaatkan teknologi informasi dan

komunikasi sehingga menggerakkan tumbuhnya industri melalui hubungan jejaring pihak-pihak yang terlibat di sebuah wilayah/kawasan industri tertentu.

\section{HASIL PENELITIAN DAN PEMBAHASAN}

\subsection{Kondisi faktual Industri Perak Batankajan}

Sentra industry kerajinan perak di Mojokerto berpusat di Desa Batankrajan,Kecamatan Gedeg, Kabupaten Mojokerto yang telah ditetapkan oleh kabupaten setempat sebagai daerah sentra industri kerajinan perak dengan menggunakan ikon sentra industri perhiasan perak. Bisnis usaha kerajinan perak dan swasa di desa Batankrajan Kecamatan Gedeg Kabupaten Mojokerto sedang lesu. Pandemi covid-19 yang menyerang mengakibatkan order sepi, bahkan dibilang tidak ada. Untuk menghadapi situasi pandemi dan bertahan kaena sepinya order, para pelaku usaha fokus pada pasar lokal melalui online. 
Meskipun minimnya pemintaan perhiasan perak di masa pandemi namun para pelaku usaha di batan krajan ini masih berusaha bertahan dalam menjalanka usahanya. Hal ini karena Kerajinan perak di Desa Batan Krajan, Kabupaten Daerah Tingkat II Mojokerto memiliki potensi besar untuk dijadikan tujuan wisata yang dapat menunjang perkembangan paiwisata daerah, khususnya cinderamata. Kerajinan perak di Desa Batan Krajan ini mempunyai daya tarik tersendiri karena sebagian penduduknya adalah pengrajin perak yang prosesnya dikerjakan dengan tangan.

Kelemahan dan permasalan yang dihadapi para pelaku industi perak Batankrajan ini antara lain kuangnya inovasi dalam pengembangan desain sehingga kurang menarik dan terkesan

kuno

,belum menerapkan manajemen mutu, terbatasnya pendidikan dan informasi akan trend dan berpengaruh pada desain, sehingga menimbulkan perhiasan perak batankrajan tidak punya identitas dan eksklusifitas desain karena hanya menggantungkan desain dari pembeli-pembeli asing,majalah-majalah,televisi yang cenderung jarang menampilkan trend fashion yang sedang berkembang. Ketidakpercayaan pengusaha UKM untuk mengembangkan ide usahanya karena terbatasnya informasi dan kemampuan dalam menciptakan ide-ide yang inovatif da kreatif, kurangnya fasilitas perkenalan atau promosi perhiasan perak Batankrajan baik di dalam negeri maupun luar negeri negeri, sehingga terkesan kurang dikenal pasar, di samping terbatasnya modal dan akses sumber pembiayaan.

\subsection{Identifikasi peran pihak-pihak yang terlibat dalam Pengembangan Sentra Industri perak Batankraja}

Industri perak batankrajan merupakan industri kreatif yang cukup potensial bagi pertumbuhn ekonomi daerah,tidak saja berperan bagi pencitraan wilayah Batankrajan sebagai sentra perak di mojokerto, tetap bisa sebagai pendorong bagi pertumbuhan wisata industri perak di kabupaten Mojokerto,pada gilirannya akan berdampak pada petumbuhan ekonomi daerah.

Perkembangan IKM perak Batankrajan cukup berkembang,meskipun mengahadapi berbagai kendala dalam pengembangannya,seperti: modal,inovasi dan teknologi produk,keersediaan SDM pefesional,dan lain yang telah menyebabkan banyaknya usaha ini merugi. Namun pada kenyataannya,masih berkembang cukup baik dan brperan penting dalam penyediaan lapangn kerja dan jumlah output yang diberikan..

Kelompok usaha ini mampu memperkerjakan banyak orang dan diharapkan mampu menciptakan dan mengembangkan usaha sampai pada skala optimalnya sehingga mampu menyediakan kesempatan kerja baru yang lebih bnyak.

Secara kelembagaan, sentra industri perak Batan krajan masih relatif sederhan karena meskipun Batankrajan telah ditetapkan sebagai kawasan industri perak unggulan di Mojokerto namun secara kelembagaan belum melibatkan pihak-pihak yang terkait dalam pengembangannya. Peran pemerintah sebagai mitra utama sangat dominan dalam rangka pembinaan para pelaku usaha/pengrajin perak sehingga permasalahan/kendala belum teratasi secara optimal. Oleh karena itu diperlukan identifikasi pihak-pihak yan terkait pengembangan shingga kendala inovasi dan daya saing perak Batankrajan dapat teratasi. Masih kurangnya peran industri pendukung dalam penyediaan infrastuktur dan permodalan dalam pengembangan sentra batan krajan belum memberikan solusi optimal, di samping itu Perguruan Tinggi sekitar belum dapat bekerjasama dengan Badan serta Pelaku Usaha.

Sebagai salah satu aktor/pihak yang terlibat dalam pengembangan yang ada dalam triple helix, pelaku industry perak batankrajan memiliki peran yang sangat penting, yaitu sebagai centre of excellence dari creator produk dan jasa kreatif, pasar baru yang dapat menyerap produk dan jasa yang dihasilkan, serta pencipta lapangan pekerjaan bagi individu-individu kreatif ataupun individu pendukung lainnya. Selain itu, pelaku bisnis juga pembentuk 
komunitas dan entrepreneur kreatif, yaitu sebagai penggerak yang membentuk ide kreatif dan pemikiran (Nuraini dan Rifzaldi Nasri,2017).

Selain pelaku usaha IKM Perak Batan krajan, Pemerintah harus terus berperan memberikan stimulus postif yang mam merangsang pertumbuhan dan perkembangan investasi bisnis serta mendorong atmosfir bisnis yang kondusif dengan cara mengurangi pembatasanpembatasan yang menyulitkan perkembangan dan inovasi dalam berbisnis,melindungi karyakarya inovsi bisnis dan mengimplentsikan aturan pmerintah yang berkaitan dengan etika dalam berbisnis sehigga tercipta persaigan yang sehat.

Pihak industri pun harus berperan aktif dalam menciptakan iklim bisnis yg baik,seperti menerapkan etika berbisnis, berkomitment pada corporate responsibility, dan menjadi mitra pemerinah dalam pertumbuhan ekonomi nasional. Lembaga-lembaga yang memproduksi pengetahuan merupakan kontibusi dalam proses inovasi karena pengetahuan merupakan elemen penting dalam pengembangn produk serta dalam penciptaan infrastruktur organisasi untuk pengembangan produk ke depan. Perluasan kosep inovasi ini, secara terpisah,menjelaskan bahwa universitas dan pemerintah menjadi actor/pihak yang terlibat yang lebih signifikan dalam proses inovasi. Universitas,pelaku bisnis dan pemerintah memainkan peranan baru dalam inovasi secara kolaboratif maupun individual (Etzkowitz,2016). Di dalam triple helix, hasil penelitian akademisi diharapkan tidak hanya melayani kebutuhan ilmu pengetahuan,namun mampu memberikan solusi bagi pemerintah di dalam menentukan regulasi yang berkaitan dengan pebisnis.

\subsection{Identifikasi Hubungan Jejaring Antar Aktor/pihak yang terlibat dalam Pengembangan Sentra perak Batan krajan}

Berdasarkan hasil identifikasi peran pihak yang terlibat dalam pengembangan sentra perak Batankajan dapat disimpulkan bahwa peran pemerintah (pusat dan daerah) sangat mendominasi dalam pengembangan sentra industri perak Batan krajan dibandingkan aktor/pihak lainnya, seperti pelaku usaha/bisnis, dan perguruan tinggi.

Pemerintah mempunyai peran dalam kemudahan akses permodalan, pengurusan perijinan dan penyiapan sarana fisik dibagi industri kreatif seperti: lokasi pasar, kegiatan pameran informasi online serta kemudahan pemasaran., disamping itu pemerintah berperan sebagai regulator yang menciptakan persaingan sehat dan iklim investasi yang kondusif bagi pelaku industri kreatif. Akademisi/Universitas berperan dalam pengembangan inovasi teknologi dan penyedia hasil riset serta menyiapkan sistem untuk tertib administrasi dan keuangan. Industri kreatif juga harus berperan dalam penyedia produk atau jasa industri ,Distribusi dan pemasaran serta pengembangan usahanya.

Hubungan antar jejaring harus mmbentuk kolaborasi yan saling mrnguntungkan sehingga diharapkan mampu menciptakan nilai tambah yang mampu bersaing. Kegiatan yang menjadi tanggung jawab bersama antara akademisi, pemerintah dan industri kreatif yaitu:

a. Kaderisasi pengusaha dengan sumber daya dari kalangan pebisnis dan diberi fasilitas pelatihan dan lainnya dari pemerintah, sedangkan pihak akademisi memberikan materi subtansi pelatihan nya sehingga di harapkan menghasilkan kader-kader yang siap bersaing.

b. Setiap usaha dikelola bersama dan pemerintah secara kontinyu melakukan kegiatan pembinaan dan pengawasan atas usaha tersebut, sedangkan pihak universitas melakukan pendampingan serta peningkatan kompetensi IKM, sehingga diharapkan industri kreatif dapat berkembang sesuai tujuan bersama.

c. Mengusahakan kemudahan atas akses permodalan, kemudahan pengurusan kredit serta tempat pemasaran hasil industri merupakan kolaborasi antar pihak pengusaha dan pemerintah. 
d. Ketersediaan sarana dan prasarana non fisik seperti penguasaan Teknologi Informasi, soft skill (kewirausahaan, kemampuan teknis dan manajerial) mutlak dimiliki dan dikembangkan oleh pelaku usaha.

Sinergi antar aktor pada konsep triple helix akan tercipta apabila masing-masing actor mampu memainkan peranannya masing-masing tanpa adanya ketergantungan dengan pihak lain. Hal tersebut mengindikasikan bahwa konsep triple helix membutuhkan jejaring yang lebih luas dalam sebuah kawasan untuk menutupi kekosongan peran antar actor/pihak yang terlibat dalam pengembangan yang sudah terjadi (Nurrahma, 2016).

Penerapan triple helix dalam pengembangan industri perak Batankrajan dapat dijabarkan sebagai berikut:

a. Peran Akademisi: Melakukan pelatihan desain, teknologi produksi, kewirausahaan, marketing, menggiatkan riset dan peningkatan kualitas bahan baku, meningkatkan kompetensi dari sisi ketrampilan, pengetahuan manajemen, bisnis digital kepada IKM kerajinan perak Batankajan.

b. Dunia Bisnis/UKM: (Self-development) mengembangkan kapasitas usaha dengan cara mengikuti sosialisasi, mengikuti workshop desain, produksi, komersialisasi dan mekanisme pembiayaan, melakukan kemitraan dengan pengusaha besar agar bisa naik kelas

c. Pemerintah: Membuat regulasi yangmendukung pengembangan industri perak, memberikan kesempatan dan menfasilitasi promosi dalam negeri dengan melakukan pameran, penghargaan kepada pelaku IKM, memberikan insetif bagi pelaku usaha untuk mengembangkan usaha, mempermudah perijinan dan akses permodalan.

\section{KESIMPULAN}

Adapun kesimpulan dalam penelitian ini adalah;

a. Jejaring merupakan kunci utama dalam pengembangan daya saing wilayah.

b. Konsep triple helix yang merupakan sinergi dan interaksi antara pemerintah intelektual/akademisi atau universitas dan pelaku usaha menjadi salah satu pendekatan untuk menciptakan sistem inovasi baik dari tata kelola maupun model bisnis sentra industri perak Batankrajan. Adanya sinergi antar pihak yang terlibat dalam pengembangan sentra Batankrajan memicu adanya penciptaan ide-ide dan pengetahuan yang akan memunculkan inovasi (Etzkowitz, 2008 dalam Nurrahma, 2016). Namun pada kenyataannya kondisi sinergi dan interaksi yang terjadi di sentra perak Batankrajan didominasi oleh pemerintah yang berperan aktif dalam pengembangan.

c. Ketergantungan pelaku IKM Perak Batan krajan terhadap sumber daya menyebabkan tidak munculnya inovasi sehingga menyebabkan pengrajin/pelaku usaha menjalankan kegiatan secara bussiness as usualkarena tidak adanya inovasi.

d. Pembentukan forum komunitas yang melibatkan ketiga aktor/pihak yang terlibat dalam pengembangan sangat diperlukan sebagai wadah komunikasi dan transfer tekonologi dalam menciptakan daya saing poduk IKM perak Batankrajan Mojokerto.

\section{DAFTAR PUSTAKA}

Alwasilah, A. Chaedar. (2015). Pokoknya Studi Kasus, Pendekatan Kualitatif. Bandung: Kiblat. Anonim. (2019). Profil Kabupaten Mojoketo,Dinas Peridustian Kabupaten Mojokerto Buchari Alma. (2019). Kewirausahaan,Alfabeta,Bandung Departemen Perdagangan (2008). Pengembangan Ekonomi Kreatif di Indonesia 2025

Dewi Eka Murniati.(2017) Peran Perguruan Tinggi Dalam Triple Helix sebagai upaya Pengembanga industri ,Fakultas Teknik Jurusan PTTB,UNY,21 November ,Procidding Seminar Nasional 'Peran Pendidikan Kejuruan Dalam Pengembangan Ekonomi Kreatif,Yogyakarta 
Febriano, Riza Muhammad; Hariyadi, A. Faroby Falatehan. Strategi Pengelolaan Kawasan Ekonomi Khusus (KEK) Sei Mangke, Klaster Industri Hilir Kelapa Sawit Terintegrasi dan Berkelanjutan. Agrica (Jurnal Agribisnis Sumatera Utara) Vol. 10 No. 1/ April 2017. Available online: http://ojs.uma.ac.id/index.php/agrica.F

Fredy Rangkuti (2015). Analisis SWOT Teknik Membedah Kasus Bisnis,PT Gramedia Pustaka Utama,Jakarta

Hamidah Nayati Utami, Sandra, Ika Ruhana(2019), Pemberdayaan Masyarakat dengan Pendekatan Triple Helix untuk Pengembangan kompetensi Wirausaha Masyarakat Desa Mandiri Energi, JIAP Vol 5, No 3, pp 294-302, 2019 ISSN 2302-2698 e-ISSN 2503-2887

Howkins,J.(2010). The creative Economy: How People Make Money from ideas, London,Penguin Books.

Michel, Porter.E. (2007). Keunggulan Bersaing. Menciptakan Mempertahankan Kinerja Unggulan,Terjemahan Bina Rupa Aksara,Jakarta

Muhammad Fakhrul Izzati, Wilopo. (2018) Implementasi Triple Helix Dalam Mendorong Pertumbuhan Industri Kreatif Di Kota Malang Sebagai Upaya Peningkatan Daya Saing Untuk Menghadapi Masyarakat Ekonomi Asean, Jurnal Administrasi Bisnis (JAB) Universitas Brawijaya Volume. 55 No 1

Nuraini dan Rifzaldi Nasri. (2017) Strategi Pengembangan Industri Kreatif DenganPendekatan Triple Helix (Studi Kasus Pada Industri Kreatif di Tangerang Selatan), Prosiding Seminar Nasional Riset Manajemen \& Bisnis 2017,"Perkembangan Konsep dan Riset EBusiness di Indonesia , ISBN: 978-602-361-067-9, h. 8

Peraturan Kepala Badan Ekonomi Kreatif Republik Indonesia Nomor 8 Tahun 2017 Tentang Rencana Strategis Badan Ekonomi Kreatif Tahun 2015 -2019

Winardi. (2008). Entrepeneur dan Enterepreneurships. Kencana Prenada Media Group,Jakarta 